\title{
Conservation in the first internal transcribed spacer (ITS1) region of Hematodinium perezi (genotype III) from Callinectes sapidus
}

\author{
Katrina M. Pagenkopp Lohan ${ }^{1,3}$, Hamish J. Small ${ }^{1}$, Jeffrey D. Shields ${ }^{1}$, \\ Allen R. Place ${ }^{2}$, Kimberly S. Reece ${ }^{1, *}$ \\ ${ }^{1}$ Virginia Institute of Marine Science, The College of William \& Mary, Gloucester Point, Virginia 23062, USA \\ ${ }^{2}$ Center of Marine Biotechnology, University of Maryland Biotechnology Institute, Baltimore, Maryland 21202, USA \\ ${ }^{3}$ Present address: Smithsonian Conservation Biology Institute, Center for Conservation and Evolutionary Genetics, \\ National Zoological Park, Washington, DC 20008, USA
}

\begin{abstract}
Hematodinium spp. infections have been reported from blue crabs Callinectes sapidus in high-salinity waters of the USA from New Jersey to Texas. Recently, H. perezi (genotype III) has been proposed as the parasite species and genotype infecting blue crabs from Virginia; however, it is unknown whether this same genotype is present in blue crabs from other locations. To address this question, we collected 317 blue crabs from Massachusetts, Virginia, Georgia, Florida, Louisiana, and Texas to test for the presence of $H$. perezi (III) using a specific PCR assay targeting the first internal transcribed spacer (ITS1) region of the ribosomal RNA gene complex. To examine the genetic variation within $H$. perezi (III), ITS1 region sequences from the parasite in blue crabs from multiple locations were compared to each other and to those of H. perezi (III) found in alternate hosts from Virginia. In total, 34 distinct ITS1 sequence variants of the parasite were identified from blue crabs alone, and 38 distinct variants were identified when alternate hosts were included. However, a single ITS1 sequence variant appeared in all geographic regions and hosts, and also in blue crabs sampled from a previous study. The high similarity among all the ITS1 region sequences examined (>98\%) and the observation of a single variant found throughout a large geographic range, strongly suggests that a single species and genotype of Hematodinium, specifically $H$. perezi (III), infects blue crabs from Virginia to Texas and multiple alternate host species in Virginia.
\end{abstract}

KEY WORDS: Dinoflagellate $\cdot$ Parasite $\cdot$ Blue crab $\cdot$ Crustacean $\cdot$ ITS1 region · Alternate hosts · Genetic variation

Resale or republication not permitted without written consent of the publisher

\section{INTRODUCTION}

Economically important fisheries for the blue crab Callinectes sapidus occur in 11 states in the USA from Delaware south to Texas (Milliken \& Williams 1984). From 1989 to 1993, average annual blue crab landings from the Atlantic and Gulf coasts exceeded 96.6 kilotons (kt) with a dockside value of US $\$ 137$ million in 1994 (Johnson et al. 1998). In the last decade, however, there have been major declines in harvest yields of many blue crab fisheries in the USA. In 2007, Chesapeake Bay had a total harvest of $19.7 \mathrm{kt}$, which was the lowest on record since 1945 (CBSAC 2010). Along coastal Georgia, blue crab landings dropped to $0.9 \mathrm{kt}$, well below the $45 \mathrm{yr}$ average of $1.8 \mathrm{kt}$ (Lee \& Frischer 2004). While data indicate that the blue crab stock in Chesapeake Bay has begun to rebound over the last $2 \mathrm{yr}$, managers have 
decided to continue stringent conservation measures until the impact of these efforts can be fully assessed (CBSAC 2010, 2012).

While many factors are believed to affect blue crab populations and fisheries (Kennedy et al. 2007), 1 potential explanation for the decline of Callinectes sapidus populations may be a parasitic dinoflagellate, Hematodinium perezi. Recent studies have shown that this species is composed of 3 distinct genotypes, with the third genotype, herein referred to as $H$. perezi (III), infecting C. sapidus in Virginia waters (Small et al. 2012). To date, infections presumably of the same genotype of $H$. perezi have been reported in adult blue crabs from New Jersey south to Texas (Messick \& Shields 2000), with prevalence ranging from 9 to $98 \%$ in some blue crab populations (Newman \& Johnson 1975, Messick 1994, Messick \& Shields 2000, Lee 2000, Gruebl et al. 2002). However, many of the reports documenting Hematodinium sp. infections in blue crabs identified the parasite based only on histological examination of tissues or hemolymph smears and did not incorporate molecular data to confirm the species or genotype of Hematodinium present. As morphological characters cannot confidently distinguish between different parasite species or genotypes within this genus (Stentiford \& Shields 2005), molecular data are necessary to confirm that the same species and genotype of Hematodinium occurs throughout this range; this has previously been suggested as a research priority by Small \& Pagenkopp (2011).

While the current molecular evidence suggests that there is 1 species of Hematodinium that appears to infect several different crustacean species from European waters (Small et al. 2007a, Hamilton et al. 2009, 2010, Eigemann et al. 2010), the North Pacific (Jensen et al. 2010), and Greenland waters (Eigemann et al. 2010), only 2 studies have used molecular techniques to examine the potential number of Hematodinium species within the blue crab range. One study demonstrated that H. perezi (III) appears to be present throughout the Delmarva Peninsula, Virginia, because of the high similarity in pathology, parasite morphology, and first internal transcribed spacer region (ITS1) region sequences from a variety of infected hosts, including blue crabs (Pagenkopp Lohan et al. 2012a). Additionally, the findings of Small et al. (2007b) suggest that $H$. perezi (III) likely occurs in Virginia and Georgia waters based on the results of a restriction fragment length polymorphism (RFLP) assay showing that the Hematodinium sp. obtained from blue crabs from Virginia and Georgia had identical pro- files on a gel. However, sequence data are needed to confirm this hypothesis.

The purpose of the current study was to investigate whether Hematodinium perezi (III) is the only genotype and species of this parasite present in blue crab populations over a wide geographic range. Sequence data from a portion of the ITS1 region of the ribosomal RNA (rRNA) gene complex were used to determine the number of genotypes of $H$. perezi present in blue crab populations from Massachusetts, Virginia, Georgia, and the Gulf of Mexico. The ITS region was chosen as it is a commonly used molecular marker for distinguishing between species and strains of freeliving dinoflagellates (LaJeunesse 2001, Litaker et al. 2007, Small et al. 2009), closely related shellfish parasites (Dungan et al. 2002, Casas et al. 2004, Dungan \& Reece 2006, Moss et al. 2008, Small 2012), and it was previously used to investigate the species and strain composition of other Hematodinium sp. isolates (Small et al. 2007a, 2012, Hamilton et al. 2009, 2010, Eigemann et al. 2010). The sequences obtained in this study from a portion of the ITS1 region of $H$. perezi were compared to ITS1 region sequences of $H$. perezi obtained from alternate hosts and to previously published ITS1 region sequences of $H$. perezi from blue crabs to examine the geographic range and temporal stability of the parasite.

\section{MATERIALS AND METHODS}

\section{Sample collection}

Blue crabs were sampled from 19 different locations in the USA (Fig. 1, Table 1). Blue crabs from the Delmarva Peninsula, Virginia, were collected via crab pots from 3 primary seaside sites (Chincoteague Bay, Wachapreague Creek, and Fisherman Island) in 2008 (May to December) and 2009 (April to December) using commercial crab pots. An additional 3 sites (Cherrystone Creek, Oyster Creek, and Metompkin Bay) were sampled only in 2008. Alternate hosts were collected as described by Pagenkopp Lohan et al. (2012a).

Blue crabs were purchased from local fisherman from 5 sites in Massachusetts (Oyster Pond, Cociut Bay, Bass River, Agawam River, and Westport River), 4 sites in Florida (Goodland, Port Charlotte, Tampa, and Panama City), 1 site in Louisiana (New Iberia), and 2 sites in Texas (Texas City and Corpus Christi Bay).

Extracted DNA samples of blue crabs infected with a species of Hematodinium from coastal Savannah, 


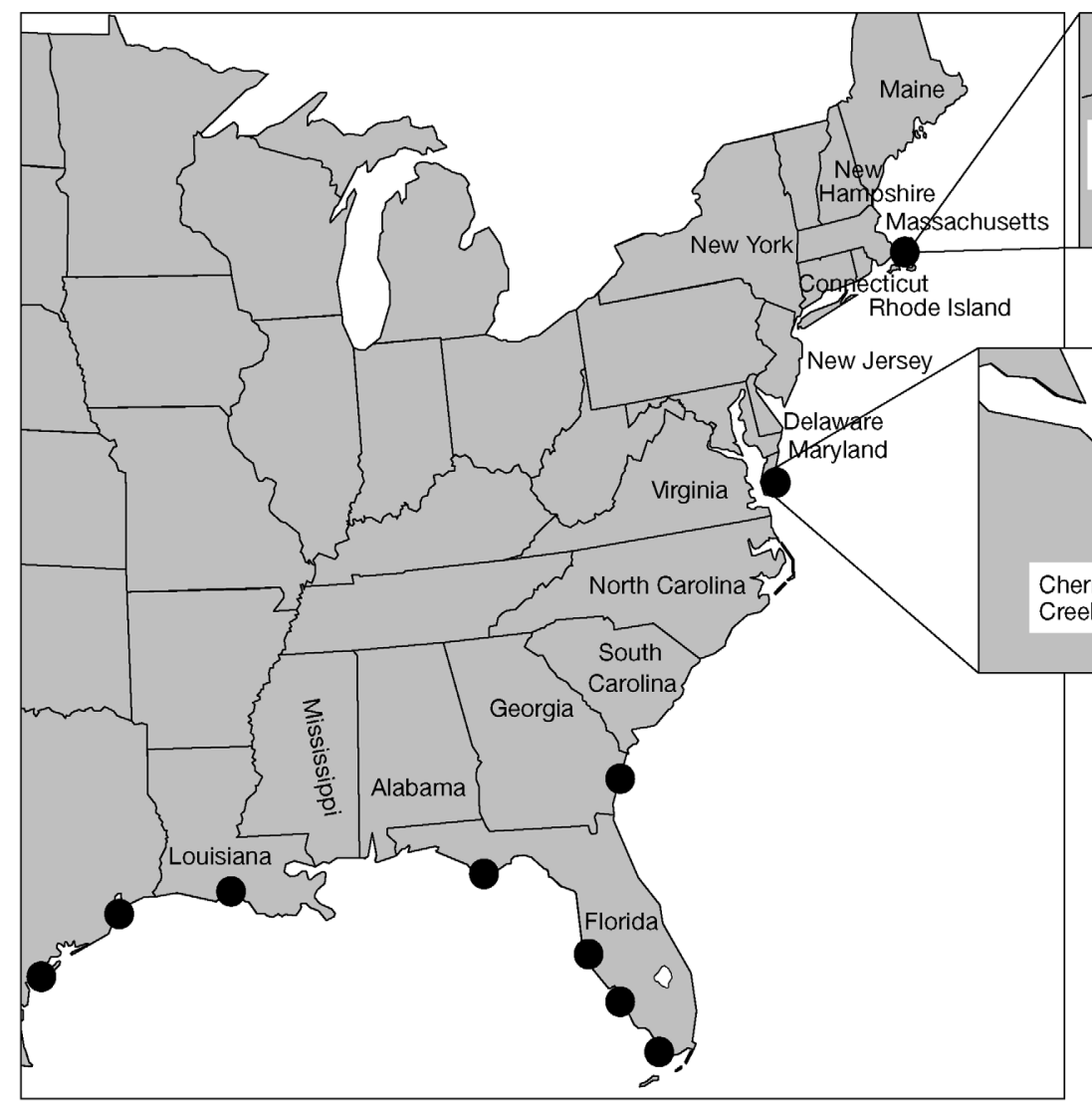

Fig. 1. Sampling locations $(\mathrm{n}=19)$ for Callinectes sapidus along the

US Atlantic and Gulf coasts

Georgia $(\mathrm{n}=8)$, collected between 2000 and 2004 were obtained from M. Frischer and R. Lee (Skidaway Institute of Oceanography). Hemolymph samples stored in $95 \%$ ethanol from blue crabs infected with a species of Hematodinium from Corpus Christi Bay, Texas $(n=7)$, were obtained from J. Gain (Texas A\&M University).

\section{Infection status}

Infection status was assessed for blue crabs and alternate hosts from Virginia as described by Pagenkopp Lohan et al. (2012a). Briefly, for blue crabs and other large crustaceans, infection status was first assessed microscopically. Hemolymph smears were stained 1:1 with $0.3 \%$ Neutral red in crab saline and examined with a light microscope at $100 \times$ and $400 \times$ magnification for uptake of the dye (see Stentiford \& Shields 2005). Mud crabs $<10 \mathrm{~mm}$ carapace width (CW) were dissected, and small pieces of gill were stained and examined as above. If Hematodinium sp. cells were observed microscopically, then hemolymph samples were saved for molecular analysis. Hemolymph samples were preserved in $95 \%$ etha- nol (500 $\mu$ l hemolymph into $500 \mu$ l of $95 \%$ ethanol) and stored at $-20^{\circ} \mathrm{C}$ for later molecular analysis. Whole crustaceans were first frozen, then transferred to $95 \%$ ethanol and stored for later molecular analysis. The infection status of the blue crab samples obtained from Massachusetts, Georgia, and the Gulf of Mexico was assessed solely via PCR (see next sub-section), as only DNA was obtained for those samples.

\section{PCR amplification and sequencing}

DNA extractions, ITS1 amplifications, and sequencing protocols for samples collected in Virginia were conducted as described by Pagenkopp Lohan et al. (2012a). Briefly, for blue crab samples, $200 \mu \mathrm{l}$ of hemolymph in $95 \%$ ethanol were extracted with the Qiagen Tissue and Blood kit following the manufacturer's protocol for animal tissue. All DNA samples were eluted in $100 \mu \mathrm{l}$ of buffer that was passed over the column twice, and incubated on the column for 5 min each time before centrifugation to increase DNA yield (Audemard et al. 2004). All extractions completed within the same day included a blank col- 
Table 1. Callinectes sapidus. Locations in the USA where blue crabs were collected or obtained. The number of C. sapidus positive for Hematodinium perezi (III) via PCR analysis from which ITS1 sequences were generated, the number of amplicons that were either directly sequenced (D) or cloned (C) prior to sequencing, and the GenBank accession numbers for the consensus or unique sequences are given

\begin{tabular}{|c|c|c|c|c|}
\hline Location & $\begin{array}{c}\text { No. } \\
\text { screened }\end{array}$ & $\begin{array}{l}\text { No. } \\
\text { positive }\end{array}$ & $\mathrm{D}$ or $\mathrm{C}$ & Accession no. \\
\hline \multicolumn{5}{|l|}{ Massachusetts } \\
\hline Martha's Vineyard, Oyster Pond & 52 & 0 & - & \\
\hline Cociut Bay Estuary & 15 & 0 & - & \\
\hline Bass River & 15 & 0 & - & \\
\hline Agawam River & 15 & 0 & - & \\
\hline Westport River & 15 & 0 & - & \\
\hline \multicolumn{5}{|l|}{ Virginia } \\
\hline Cherrystone Creek & 6 & 6 & $\mathrm{D}$ & JN380145-JN380147，JN380157，JN380169，JN380091 \\
\hline Oyster Creek & 5 & 5 & $\mathrm{D}$ & JN380148-JN380149, JN380162-JN380163, JN380166 \\
\hline Metompkin Bay & 5 & 5 & $\mathrm{D}$ & JN380150, JN380158-JN380160，JN380165 \\
\hline Chincoteague Bay & 8 & 8 & $\mathrm{D}=4, \mathrm{C}=4$ & JN380144，JN380152-JN380155, JN380173-JN380176 \\
\hline Wachapreague Creek & 6 & 6 & $\mathrm{D}=3, \mathrm{C}=3$ & $\begin{array}{l}\text { JN380151，JN380161，JN380164，JN380170-JN380172, } \\
\text { KC192761-KC192763 }\end{array}$ \\
\hline Fisherman's Island & 6 & 6 & $\mathrm{D}=4, \mathrm{C}=4$ & $\begin{array}{l}\text { JN380156, JN380167-JN380168, JN380177-JN380179, } \\
\text { KC192749-KC192753 }\end{array}$ \\
\hline \multicolumn{5}{|l|}{ Georgia } \\
\hline Savannah & 8 & 8 & $\mathrm{C}$ & JN380092-JN380113 \\
\hline \multicolumn{5}{|l|}{ Florida } \\
\hline Goodland & 16 & 2 & $\mathrm{C}$ & JN380114-JN380116 \\
\hline Port Charlotte & 3 & 0 & - & \\
\hline Tampa & 17 & 1 & $\mathrm{C}$ & JN380124, KC192754 \\
\hline Panama City & 21 & 5 & $\mathrm{C}$ & JN380117-JN380123, KC192755-KC192760 \\
\hline \multicolumn{5}{|l|}{ Louisiana } \\
\hline New Iberia & 31 & 0 & - & \\
\hline \multicolumn{5}{|l|}{ Texas } \\
\hline Texas City & 36 & 0 & - & \\
\hline Corpus Christi & 38 & 7 & $\mathrm{C}$ & JN380125-JN380143 \\
\hline Total & 318 & 59 & 186 & \\
\hline
\end{tabular}

umn extraction, which, when subjected to PCR analysis alongside samples, served as a control for extraction contamination. After extraction, the DNA was aliquoted $(\sim 20 \mu \mathrm{l})$ to avoid contamination of the entire stock of extracted DNA. The remaining stock DNA $(\sim 80 \mu \mathrm{l})$ was stored at $-20^{\circ} \mathrm{C}$ and the $20 \mu \mathrm{l}$ aliquot was stored at $4{ }^{\circ} \mathrm{C}$. Extracted DNA was quantified using a NanoDrop 2000 (Thermo Scientific).

For blue crabs collected from the Gulf of Mexico, genomic DNA isolation involved solubilization in a $10 \%$ cetylmethylammoniumbromide (CTAB) solution, followed by a phenol:chloroform extraction (Grabowski \& Stuck 1999). For blue crabs collected from Massachusetts, genomic DNA was extracted from approximately $100 \mathrm{mg}$ of muscle from a walking leg using the Qiagen Tissue and Blood kit according to the manufacturer's instructions. DNA was eluted off the column twice with $50 \mu$ l of water and quantified using a Nanodrop ND-1000 spectrophotometer (Thermo Scientific). Genomic DNA extracted from blue crabs from the Gulf of Mexico and Massachu- setts was diluted to a stock concentration of $10 \mathrm{ng}^{-1}$ prior to PCR amplification.

To confirm the presence of high molecular weight DNA in extractions, a general metazoan primer set, nSSU A and nSSU B (modified from Medlin et al. 1988, see Moss et al. 2007) was used to amplify DNA extracted from samples. A second PCR assay using the primers HITS1F and HITS1R, which amplify a 302 base pair (bp) portion of the ITS1 region of Hematodinium perezi (Small et al. 2007b), was used to confirm infection status. For some of the samples from the Mexican Gulf of Mexico coast of Florida, 2 rounds of the ITS1 PCR were performed to increase the number of amplicons available for cloning. These PCRs were conducted as described above with $5 \mu$ of DNA in the first amplification, and $0.5 \mu \mathrm{l}$ from the first amplification was used as the template for a second amplification. A third PCR assay using primers Hemat-F-1487 and Hemat-R-1654, a modified version of the Gruebl et al. (2002) assay, which amplifies a 187 bp portion of the SSU rRNA gene of all known 
members of the genus Hematodinium, was applied to blue crab samples from Massachusetts and the Gulf of Mexico due to the possibility of encountering other species of Hematodinium in these locations. A negative control, consisting of no DNA, was included in all of the diagnostic PCR assays, and a positive control, consisting of either DNA extracted from a culture of $H$. perezi (III) or a sample that had reliably amplified in the past, was also included in all diagnostic PCR assays.

The ITS1 region PCR products were cloned and sequenced as described by Moss et al. (2008) or sequenced directly. Prior to cloning, those amplicons from samples from the Gulf Coast of Florida that were produced through 2 rounds of PCR were first excised from the agarose gel. The excised PCR products were purified using a Qiagen gel extraction kit (Qiagen) and eluted in $30 \mu \mathrm{l}$ of buffer. Amplicons of a portion of the ITS1 region were cloned with a TOPO TA cloning kit (Invitrogen) using half of the total volume of cells recommended by the manufacturer's instructions. Plasmid DNA was extracted from individual colonies following a boil-prep method, and colonies were screened using the M13 F/R vector primers supplied in the cloning kit. An aliquot of the PCR products (5 $\mu \mathrm{l})$ was visualized under UV light on a $2 \%(\mathrm{w} / \mathrm{v})$ agarose gel after ethidium bromide staining. PCR products of the expected size based on the insert (302 bp) and flanking vector region amplified with the M13 primers ( 500 bp) were purified with exonuclease I (EXO) and shrimp alkaline phosphatase (SAP). The purified PCR product was used as the template for sequencing with M13 F/R primers and the Big Dye Terminator kit (Applied Biosystems) using 1/8 of the reaction size recommended by the manufacturer. All samples were bidirectionally sequenced. The sequence reactions were precipitated using an ethanol/sodium acetate protocol (ABI User Bulletin 2002). The precipitated sequencing products were resuspended in Hi-Di formamide (Applied Biosystems) and electrophoresed on a 3130xl Genetic Analyzer (Applied Biosystems).

For the samples from Georgia, 3 to 4 clones per sample were sequenced. For the samples from the Gulf Coast of Florida, 1 to 5 clones per sample were sequenced. For the additional 7 samples from Texas, 7 to 8 clones per sample were sequenced. For the 6 samples from Virginia whose amplicons were cloned, 1 to 4 clones per sample were sequenced. Due to the low variability observed previously, and to reduce the cost per sample, the majority of samples from Virginia were directly sequenced.

\section{Sequence analysis}

Sequences were edited in CodonCode Aligner and were aligned and compared using CodonCode Aligner and MacClade 4.07 OSX (Madison \& Madison 2005) to determine similarity. When clones from the same sample showed identical ITS1 region sequences, the consensus sequence for the clones was used in the analyses. The sequences from this study were then compared to Hematodinium perezi (III) sequences from infected blue crabs collected in 2005, which were previously deposited in GenBank (Small et al. 2007b; accession numbers DQ925227-DQ925236), to determine whether there were changes in the ITS1 sequences of the parasites over time in Virginia coastal waters. An alignment with all of the ITS1 region consensus sequences of Hematodinium sp. from blue crabs was run through TCS 1.21 (http://darwin.uvigo.es/software/tcs.html; Templeton et al. 1992), with gaps as a fifth state, to determine whether any geographic groupings occurred. ITS1 sequence variants were defined as consensus sequences that differed by at least $1 \mathrm{bp}$ or indel.

A second TCS 1.21 analysis was conducted as described above, which combined the Hematodinium perezi (III) ITS1 region sequences obtained from the above blue crab sequences and those obtained from alternate hosts (Pagenkopp Lohan et al. 2012a; accession numbers JN368149-JN368194), to determine whether any host groupings occurred.

Lastly, ITS1 region sequences from Hematodinium perezi genotypes I and II (Small et al. 2012) were downloaded from GenBank (accession numbers EF065708-EF065716, EF153724EF153727, EF173451-EF173454) and added to the alignment of parasite ITS1 region sequences from blue crabs from this study, the previously deposited ITS1 sequences of $H$. perezi (III) from blue crabs, and those from alternate hosts. This alignment was used to calculate the average genetic distances between the sequences in MEGA 5.05 (Tamura et al. 2011). For this calculation, the partial ITS1 region sequences were combined into 4 groups: ITS1 region sequences from $H$. perezi (I) from GenBank, ITS1 region sequences from $H$. perezi (II) from GenBank, ITS1 region sequences from $H$. perezi (III) from alternate hosts, and ITS1 region sequences from $H$. perezi (III) from Callinectes sapidus. Genetic distance was calculated with a partial deletion of gaps and missing data with site coverage cutoff at $95 \%$ and a p-distance model. 


\section{RESULTS}

In total, 186 sequences and 97 consensus sequences of a portion of the ITS1 region of Hematodinium sp. were obtained from infected blue crabs from 10 of the 19 locations surveyed (Fig. 1, Table 1). Hematodinium sp. DNA was not amplified from any blue crabs from Massachusetts or Louisiana using either of the parasite PCR assays. Hematodinium sp. DNA was amplified with both parasite PCR assays from 8 blue crabs from Georgia, 7 blue crabs from Texas, and 11 blue crabs from the Gulf Coast of Florida (Table 1). Hematodinium sp. DNA was amplified from 1 sample from Panama City, Florida, with the parasite SSU PCR assay, but not with the parasite ITS1 PCR assay. Although weak amplicons were observed, ITS1 region sequences of Hematodinium could not be obtained from 2 additional samples from Florida (1 from Tampa and 1 from Panama City). As no ITS1 sequence data were obtained from these 3 blue crabs from Florida, they were excluded from the analysis.

Of those parasite sequences obtained from blue crab hosts, 34 distinct ITS1 sequence variants were observed; however, 1 variant was observed in all geographic regions $(\mathrm{n}=43$ consensus sequences; Fig. 2). Six of the 9 sequences from the 2005 study matched the most common ITS1 variant from this study, while the other 3 sequences from 2005 differed from the most common ITS1 variant by a single nucleotide substitution or indel. From 34 amplicons, 161 clones were sequenced from a portion of the ITS1 region of Hematodinium sp. (Table 2). Of these cloned sequences, $74 \%(\mathrm{n}=118)$ were the most common ITS1 variant observed, $17 \%(n=28)$ matched another clone that was not the most common ITS1 variant, and $9 \%(\mathrm{n}=15)$ were only observed a single time. The sampling site with the most unique ITS1 consensus sequences was Georgia $(\mathrm{n}=11)$, although most of these sequences differed by only a single nucleotide polymorphism or indel. Only the most common ITS1 variant was detected in the amplicons from blue crabs that were directly sequenced.

When ITS1 region sequences of the parasite from alternate hosts were combined with those from blue crabs, a total of 38 distinct ITS1 sequence variants were observed (Fig. 3). The most common ITS1 variant was observed in all hosts examined ( $\mathrm{n}=58$ consensus sequences). Six additional ITS1 variants were observed either in multiple locations or in multiple host species. Of the 40 clones obtained from alternate hosts, $80 \%(\mathrm{n}=32)$ were the most common ITS1 variant observed, $10 \%(\mathrm{n}=4)$ matched another clone that was not the most common ITS1 variant, and 10\% $(\mathrm{n}=4)$ were only observed a single time (Table 3 ). With the exception of a single amplicon obtained

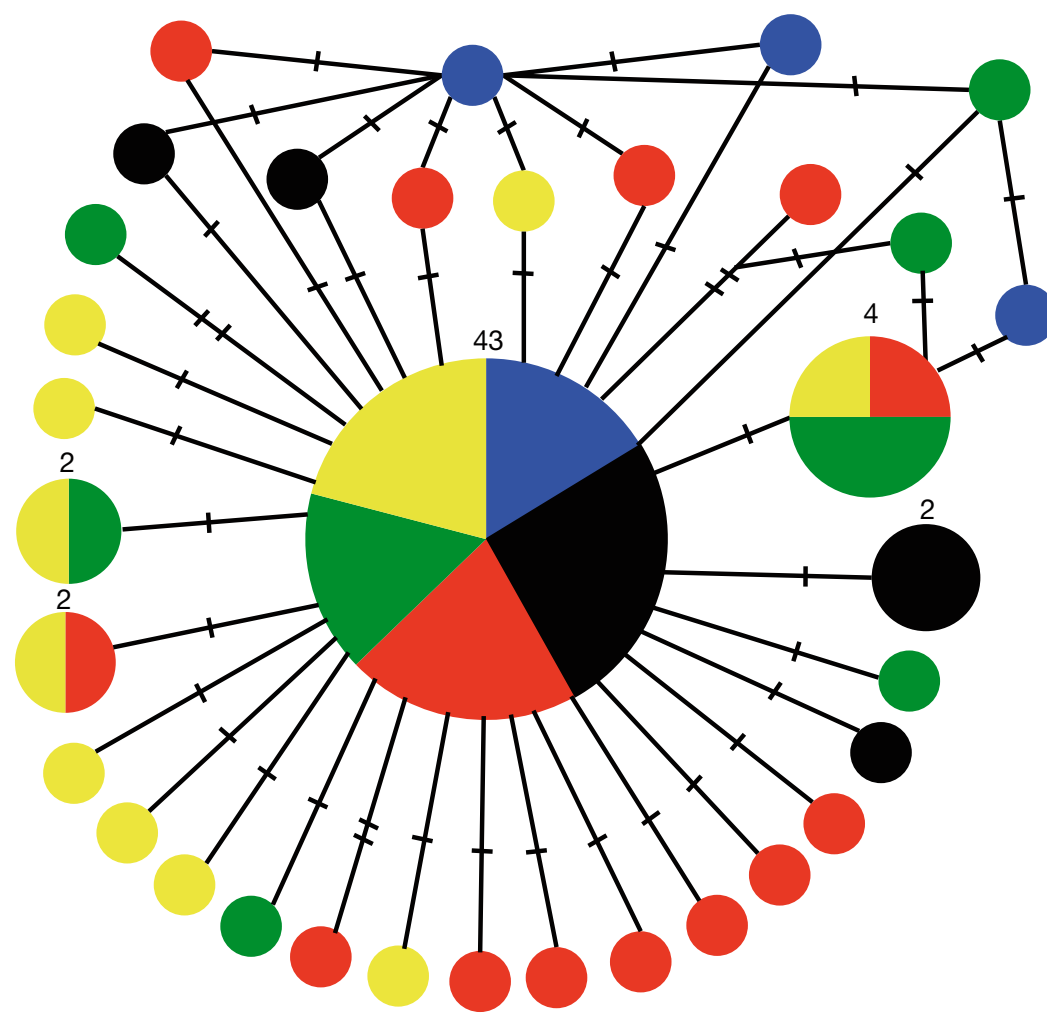

Callinectes sapidus Virginia 2005

Callinectes sapidus Virginia 2008-2009

Callinectes sapidus Georgia

Callinectes sapidus Gulf Coast of Florida

Callinectes sapidus Texas

Fig. 2. Hematodinium perezi (III). ITS1 region sequences were PCR amplified and cloned from 59 infected Callinectes sapidus. A modified TCS network was generated using these sequences indicating 34 distinct ITS1 sequence variants. Each dash indicates a single nucleotide polymorphism or a gap. The center circle represents the variant that was common to all locations. As all directly sequenced amplicons were identical to the most common variant, these amplicons were not included in this analysis. Numbers above the circles indicate the number of consensus sequences obtained from cloned amplicons that are represented. The shading for those circles with $>1$ sequence indicates the portion of consensus sequences obtained from C. sapidus individuals from that geographic location. Those circles without numbers represent only a single consensus sequence 
Table 2. Hematodinium perezi (III). ITS1 region amplicons (obtained from infected Callinectes sapidus) that were cloned and sequenced. The number of sequences obtained from each location is indicated, as well as the number of clones that matched the most common ITS1 variant (most common seq.), the number that did not match any other sequences (unique seqs.), and the number that matched at least 1 other sequence in this study (shared seq.)

\begin{tabular}{|lcrrrrr|}
\hline \multirow{2}{*}{$\begin{array}{c}\text { Location } \\
\text { ampli- }\end{array}$} & $\begin{array}{c}\text { No. } \\
\text { cons } \\
\text { cloned }\end{array}$ & quenced & $\begin{array}{c}\text { Nost } \\
\text { common } \\
\text { seq. }\end{array}$ & $\begin{array}{c}\text { Unique } \\
\text { seqs. }\end{array}$ & $\begin{array}{c}\text { Shared } \\
\text { seq. }\end{array}$ \\
\hline Chincoteague Bay, VA & 4 & 12 & 9 & 2 & 1 \\
Wachapreague Creek, VA & 3 & 12 & 11 & 1 & 0 \\
Fisherman's Island, VA & 4 & 16 & 14 & 0 & 2 \\
Savannah, GA & 8 & 30 & 15 & 12 & 3 \\
Goodland, FL & 2 & 6 & 4 & 0 & 2 \\
Tampa, FL & 1 & 6 & 5 & 1 & 0 \\
Panama City, FL & 5 & 25 & 17 & 4 & 4 \\
Corpus Christi, TX & 7 & 54 & 43 & 8 & 3 \\
Total & 34 & 161 & 118 & 28 & 15 \\
\hline
\end{tabular}

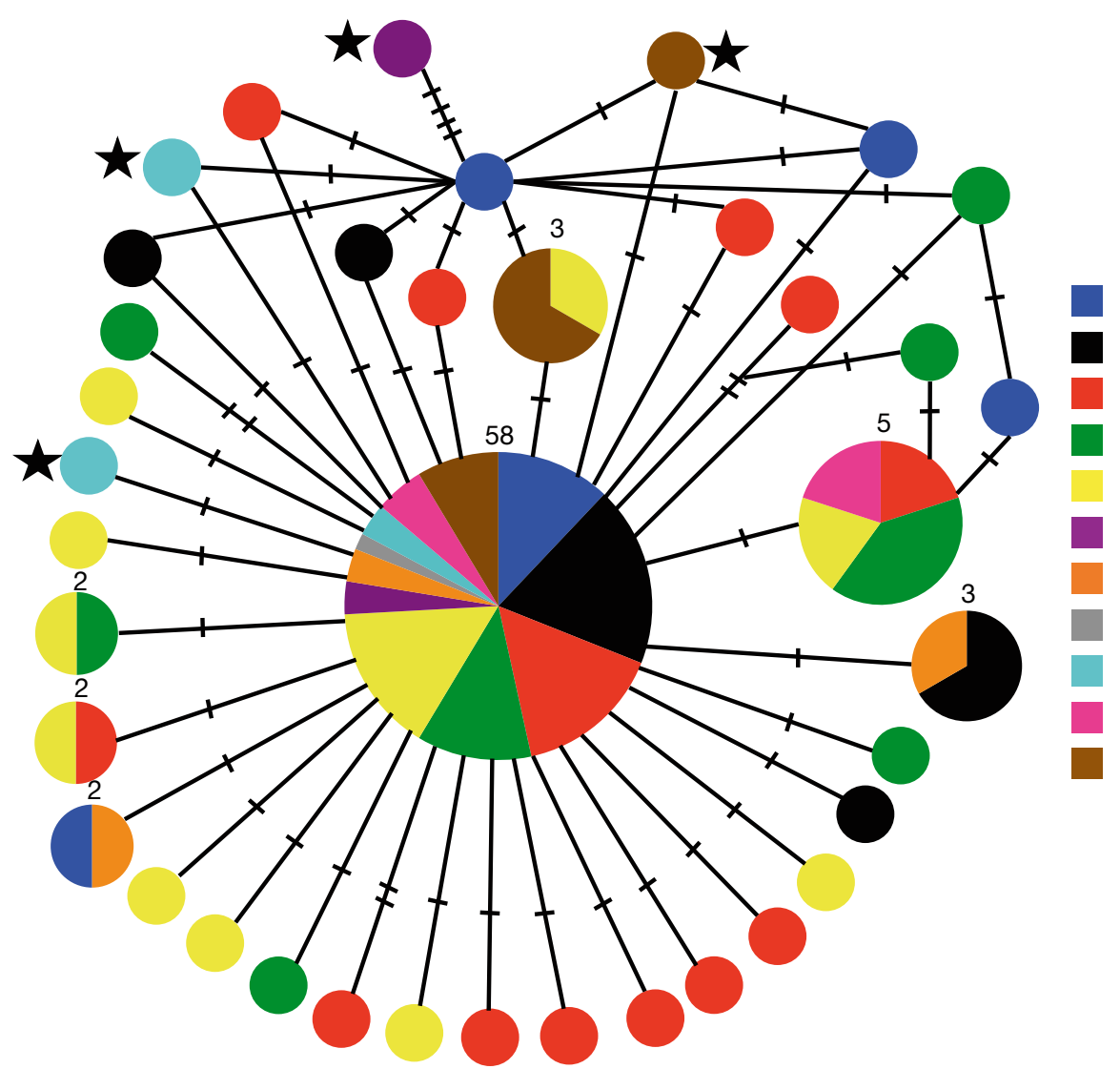

from an infected $<10 \mathrm{~mm}$ mud crab, the remaining directly sequenced amplicons obtained from infected alternate hosts were all identical to the most common ITS1 variant.

The average genetic distance between the partial ITS1 region sequences of Hematodinium perezi (III) obtained from Callinectes sapidus and the alternate hosts was only 0.002 (99.8\% similarity) with the genetic distance ranging between 0 and 0.016 (100 to $98.4 \%$ similarity). The average genetic distances between the ITS1 region sequences from $H$. perezi (I) infecting Liocarcinus depurator from the English Channel, the ITS1 region sequences from $H$. perezi (III) obtained from $C$.

Callinectes sapidus Virginia 2005

Callinectes sapidus Virginia 2008-2009

Callinectes sapidus Georgia

Callinectes sapidus Gulf Coast of Florida

Callinectes sapidus Texas

Libinia emarginata

Libinia dubia

Panopeus herbstii

Pagurus pollicaris

Mud crabs $<10 \mathrm{~mm} \mathrm{CW}$

Caprella geometrica

Fig. 3. Hematodinium perezi (III). ITS1 region sequences were PCR amplified and cloned from 59 infected Callinectes sapidus and 37 alternate host species. A modified TCS network was generated using these sequences indicating 38 distinct ITS1 sequence variants. The center circle represents a variant that was common to all locations and host species. As in Fig. 2, all directly sequenced amplicons that matched the most common variant were not included in this analysis, which includes all but 1 directly sequenced amplicon from an alternate host (mud crab $<10 \mathrm{~mm}$ carapace width, CW), which was included. Each dash indicates a single nucleotide polymorphism or a gap. Stars indicate the 4 ITS1 variants observed only in alternate host species. Numbers above the circles indicate the number of consensus sequences represented. Those circles without numbers represent only a single consensus sequence 
Table 3. Hematodinium perezi (III). ITS1 region sequences from alternate hosts that were included in the second TCS analysis. The numbers of samples that were PCR positive for $H$. perezi and the numbers of amplicons obtained via direct sequencing (D) or cloning (C) are listed, as well as the total number of clones obtained, the number of clones that matched the most common ITS1 variant, the number that did not match any other sequences (unique sequences), and the number that matched at least 1 other sequence in this study

\begin{tabular}{|c|c|c|c|c|c|c|c|}
\hline \multirow{2}{*}{ Species } & \multirow{2}{*}{$\begin{array}{c}\text { No. } \\
\text { positive }\end{array}$} & \multirow{2}{*}{$\mathrm{D}$ or $\mathrm{C}$} & \multicolumn{4}{|c|}{ Number of clones } & \multirow{2}{*}{$\begin{array}{c}\text { GenBank } \\
\text { accession no. }\end{array}$} \\
\hline & & & Sequenced & $\begin{array}{l}\text { With most } \\
\text { common } \\
\text { sequence }\end{array}$ & $\begin{array}{c}\text { With } \\
\text { unique } \\
\text { sequences }\end{array}$ & $\begin{array}{c}\text { With } \\
\text { shared } \\
\text { sequence }\end{array}$ & \\
\hline Libinia emarginata & 2 & $\mathrm{C}$ & 6 & 5 & 1 & 0 & JN368149-51 \\
\hline Libinia dubia & 3 & $\mathrm{D}=1, \mathrm{C}=2$ & 6 & 4 & 0 & 2 & JN368152-56 \\
\hline Pagurus pollicaris & 2 & C & 8 & 6 & 2 & 0 & JN368157-60 \\
\hline Eurypanopeus depressus & 3 & $\mathrm{D}$ & - & - & - & - & JN368161-63 \\
\hline Panopeus herbstii & 3 & $\mathrm{D}=2, \mathrm{C}=1$ & 3 & 3 & 0 & 0 & JN368164-66 \\
\hline Caprella geometrica & 3 & $\mathrm{C}$ & 8 & 5 & 1 & 2 & JN368187-94 \\
\hline Mud crabs $<10 \mathrm{~mm}$ & 21 & $\mathrm{D}=17, \mathrm{C}=3$ & 9 & 9 & 0 & 0 & JN368167-86 \\
\hline Total & 37 & 63 & 40 & 32 & 4 & 4 & \\
\hline
\end{tabular}

sapidus, and those from the alternate hosts were 0.045 (95.5\% similarity) and 0.044 (95.6\% similarity), respectively, with the genetic distances ranging between 0.039 and 0.055 (96.1 to $94.5 \%$ similarity). The average genetic distances between the ITS1 region sequences from $H$. perezi (II) infecting Scylla serrata and Portunus trituberculatus from China, the ITS1 region sequences from $H$. perezi (III) obtained from C. sapidus, and those from the alternate hosts were 0.036 (96.4\% similarity) and 0.036 (96.4\% similarity), respectively, with the genetic distances ranging between 0.027 and 0.044 (97.3 to 95.6\% similarity).

\section{DISCUSSION}

Based on the high similarity (>99\%) among the partial sequences of the ITS1 region obtained in this study, we conclude that Hematodinium perezi (III) is the only species and genotype of Hematodinium infecting blue crabs from Virginia to Texas. In addition, this same species and genotype infects other crustaceans in the coastal waters of Virginia based on the $>98 \%$ similarity observed among all Hematodinium sp. sequences from the region. The average genetic distance between the partial sequences of the ITS1 region of $H$. perezi (III) from the US and those from $H$. perezi (I) from Europe and $H$. perezi (II) from China is approximately 20 times greater than the average genetic distance among the sequences in crustacean hosts from the US Atlantic and Gulf coasts, providing additional evidence that $H$. perezi (III) is the only species and genotype of Hematodinium currently found in the region.
Many studies on geographic variation, population structure, and identification of different species of phytoplankton have used variable regions of the genome, such as the ITS1 of the rRNA gene complex (Kooistra et al. 2001, Litaker et al. 2003, Ki \& Han 2007, Zheng et al. 2008). Although the level of intraspecific variation in the ITS1 region for Hematodinium perezi (III) appears to be fairly low throughout this geographic region, it is consistent with what has been reported in other molecular studies on Hematodinium species (Hamilton et al. 2007, 2009, Small et al. 2007a,b, 2012, Eigemann et al. 2010); however, a direct comparison cannot be made between this study and those that used direct sequencing techniques (Hamilton et al. 2007, 2009, Eigemann et al. 2010) because some of the variation may not have been detected in those studies. In addition, the level of intracellular variation among the multiple copies of the ITS regions in the genome of this parasite has yet to be determined because clonal cultures have not been established. Therefore, we could not distinguish between genetic variations among the multiple ITS1 region sequences within a single parasite cell and multiple sequence variants from infections of multiple parasite strains within a single host individual (Pagenkopp Lohan et al. 2012b).

We found no genetic differentiation among Hematodinium perezi (III) populations from the US Atlantic coast and Gulf of Mexico based on the partial ITS1 region sequences. Previous studies have discovered population differentiation due to vicariance in several marine and estuarine species between the Atlantic coast and Gulf of Mexico using various types of genetic markers (Avise 1992, Pelc et al. 2009). Such studies have provided insight into the historical 
expansion and contraction of the ranges of those species. However, population differentiation along the US Atlantic and Gulf coasts has only been examined for 1 marine parasite, Perkinsus marinus (Reece et al. 2001). In that study, different allele frequencies among 3 regions of the USA were found: Northeast Atlantic, Southeast Atlantic, and Gulf of Mexico. In the blue crab host for H. perezi (III), no genetic population structure has been detected along the US Atlantic seaboard and Gulf of Mexico using RFLP analysis of mtDNA (McMillen-Jackson \& Bert 2004); however, there was a notable decline in genetic variation with increasing latitude along the eastern seaboard.

Although the ITS1 region is generally recognized as evolving more rapidly than other portions of the rRNA gene complex (Schlötterer et al. 1994), we found low variation in this region in Hematodinium perezi (III) from Virginia to Texas. Samples from Georgia had the largest number of unique ITS1 consensus sequences, but the majority of these sequences differed by a single nucleotide polymorphism or indel. Two scenarios may explain the low variation in the ITS1 region. First, the data are consistent with a relatively recent introduction event followed by rapid dispersal over a wide geographic region. Small et al. (2012) hypothesized that $H$. perezi may have spread from the waters of the UK to the east coast of the USA through various mechanisms including the unintentional introduction of infected Carcinus maenas, an invasive species, via ballast transfer. If $H$. perezi (III) was introduced to the east coast of the USA, it may have rapidly spread through the Atlantic and Gulf of Mexico coastal waters, either through dispersal of a potential free-living stage (Frischer et al. 2006, Li et al. 2010), through host movement and further introductions, or as a host generalist (Pagenkopp Lohan et al. 2012a) through infection of a broad number of hosts with consequent dispersal, leaving little time for the ITS1 region to accumulate mutations. While we do not know exactly how long $H$. perezi (III) has been present along the east coast of the USA, it was first discovered infecting blue crabs in 1968 by Newman \& Johnson (1975). At the time of their sampling, the parasite was already present in South Carolina, Georgia, and Florida.

A second possible mechanism for the low variation in the ITS1 region of Hematodinium perezi (III) is that this locus is conserved due to a functional role. The spacer regions of the ribosomal gene complex are involved in the processing of primary RNA transcripts in yeast (Musters et al. 1990, Lalev et al. 2000), and conservation in the secondary structure of the
ITS1 region has been observed in Hematodinium (Jensen et al. 2010) and other species of dinoflagellates (Gottschling \& Plötner 2004). This latter finding may be attributable to a potential functional significance for this locus in dinoflagellates. However, the length of the spacer region that is needed to perform this function is unknown, and the majority of the ITS1 region appears to evolve at the same rate as neutral loci in multiple Drosophila species (Schlötterer et al. 1994).

In conclusion, partial ITS1 region sequences obtained from Hematodinium-infected blue crabs collected from various geographic locations and alternate hosts indicate that the same $H$. perezi genotype infects blue crabs from Virginia to Texas, and that it is capable of infecting a wide variety of other hosts. Although the ITS1 region sequences did not demonstrate any genetic population structure for $H$. perezi (III) in the geographic range examined, additional molecular markers with higher resolution, such as the microsatellite markers recently developed for this parasite (Pagenkopp Lohan et al. 2012b), may be able to elucidate genetic population structure or provide further strain-level partitioning over a similar geographic range.

Acknowledgements. We thank J. Gain, M. Frischer, and $\mathrm{R}$. Lee for the blue crab samples from additional locations. We are grateful to those who helped with the sample processing in Virginia, including J. Moss Small, C. Li, T. Dolan, K. Wheeler, A. Coffey, P. Coffey, C. Magel, K. Delaney, A. Dersham, B. J. Peemoeller, and D. Gibbs. We thank S. Fate, A. Birch, and E. Smith of the VIMS Eastern Shore Laboratory for their critical roles in obtaining samples. G. Scott, A. MacIntyre, and A. Dershem assisted with the molecular laboratory work. J. McDowell provided helpful comments and suggestions on an earlier version of this manuscript. This project was funded by EID Program Grant, NSF OCE BE-UF no. 0723662. This is VIMS contribution number 3255 and number 4712 from the University of Maryland Center for Environmental Sciences.

\section{LITERATURE CITED}

ABI User Bulletin (2002) Precipitation method to remove unincorporated dye terminators from ABI Prism BigDye Terminator v3.0 cycle sequencing reactions. Applied Biosystems, Foster City, CA. Available at http://tools. invitrogen.com/content/sfs/manuals/cms_041276.pdf

Audemard C, Reece KS, Burreson EM (2004) Real-time PCR for detection and quantification of the protistan parasite Perkinsus marinus in environmental waters. Appl Environ Microbiol 70:6611-6618

> Avise JC (1992) Molecular population structure and the biogeographic history of a regional fauna: a case history with lessons for conservation biology. Oikos 63:62-76 
Casas SM, Grau A, Reece KS, Apakupakul K, Azevedo C, Villalba A (2004) Perkinsus mediterraneus n. sp., a protisan parasite of the European flat oyster Ostrea edulis from the Balearic Islands, Mediterranean Sea. Dis Aquat Org 58:231-244

CBSAC (Chesapeake Bay Stock Assessment Committee) (2010) 2010 Chesapeake Bay blue crab advisory report. NOAA, Chesapeake Bay Office. Available at http:// chesapeakebay.noaa.gov/images/stories/fisheries/key FishSpecies/cbsacreport2010.pdf (accessed 27 Feb 2013)

CBSAC (2012) 2012 Chesapeake Bay blue crab advisory report. NOAA, Chesapeake Bay Office. Available at www. chesapeakebay.net/documents/CBSAC_Final_Advisory_ Report_2012_July_20th_2012.pdf (accessed 27 Feb 2013)

> Dungan CF, Reece KS (2006) In vitro propagation of two Perkinsus spp. parasites from Japanese manila clams Venerupis philippinarum and description of Perkinsus honshuensis n. sp. J Eukaryot Microbiol 53:316-326

Dungan CF, Hamilton RM, Hudson KL, McCollough CB, Reece KS (2002) Two epizootic diseases in Chesapeake Bay commercial clams Mya arenaria and Tagelus plebeius. Dis Aquat Org 50:67-78

- Eigemann F, Burmeister A, Skovgaard A (2010) Hematodinium sp. (Alveolata, Syndinea) detected in marine decapod crustaceans from waters of Denmark and Greenland. Dis Aquat Org 92:59-68

Frischer ME, Lee RF, Sheppard MA, Mauer A and others (2006) Evidence for a free-living stage of the blue crab parasitic dinoflagellate, Hematodinium sp. Harmful Algae 5:548-557

Gottschling M, Plötner J (2004) Secondary structure models of the nuclear internal transcribed spacer regions and 5.8s rRNA in Calciodinelloideae (Peridiniaceae) and other dinoflagellates. Nucleic Acids Res 32:307-315

Grabowski M, Stuck KC (1999) Structure and intraspecific variability of the control region mtDNA in the pink shrimp, Farfantepenaeus duorarum (Decapoda: Penaeidae) In: Schram FR, von Vaupel Klein JC (eds) Crustaceans and the biodiversity crisis. Proc 4 th Int Crustac Congr. Brill Publishers, Leiden, p 333-344

> Gruebl T, Frischer ME, Sheppard M, Neumann M, Maurer AN, Lee RF (2002) Development of an 18S rRNA gene targeted PCR based diagnostic for the blue crab parasite Hematodinium sp. Dis Aquat Org 49:61-70

Hamilton KM, Morritt D, Shaw PW (2007) Molecular and histological identification of the crustacean parasite Hematodinium (Alveolata, Syndinea) in the shore crab Carcinus maenas. Acta Protozool 46:183-192

Hamilton K, Shaw P, Morritt D (2009) Prevalence and seasonality of Hematodinium (Alveolata: Syndinea) in a Scottish crustacean community. ICES J Mar Sci 66: 1837-1845

> Hamilton KM, Morritt D, Shaw PW (2010) Genetic diversity of the crustacean parasite Hematodinium (Alveolata, Syndinea). Eur J Protistol 46:17-28

> Jensen PC, Califf K, Lowe V, Hauser L, Morado JF (2010) Molecular detection of Hematodinium sp. in Northeast Pacific Chionoecetes spp. and evidence of two species in the Northern Hemisphere. Dis Aquat Org 89:155-166

Johnson AJ Jr, Green DP, Martin RE (1998) Industry perspectives: the hard blue crab fishery - Atlantic and Gulf. J Shellfish Res 17:371-374

Kennedy VS, Oesterling M, van Engel WA (2007) History of blue crab fisheries on the U.S. Atlantic and Gulf Coasts. In: Kennedy VS, Cronin LE (eds) The blue crab: Calli- nectes sapidus. Maryland Sea Grant, College Park, MD, p 655-710

Ki JS, Han MS (2007) Cryptic long internal repeat sequences in the ribosomal DNA ITS1 gene of the dinoflagellate Cochlodinium polykrikoides (Dinophyceae): a $101 \mathrm{nu}-$ cleotide six-repeat track with a palindrome structure. Genes Genet Syst 82:161-166

> Kooistra WHCF, de Boer MK, Vrieling EG, Connell LB, Gieskes WWC (2001) Variation along ITS markers across strains of Fibrocapsa japonica (Raphidophyceae) suggests hybridization events and recent range expansion. J Sea Res 46:213-222

> LaJeunesse TC (2001) Investigating the biodiversity, ecology, and phylogeny of endosymbiotic dinoflagellates in the genus Symbiodinium using the ITS region: in search of a 'species' level marker. J Phycol 37:866-880

> Lalev AI, Abeyrathne PD, Nazar RN (2000) Ribosomal RNA maturation in Schizosaccharomyces pombe is dependent on a large ribonucleoprotein complex of the internal transcribed spacer 1. J Mol Biol 302:65-77

Lee RF, Frischer ME (2004) The decline of the blue crab. Am Sci 92:548-553

Li C, Shields JD, Miller TL, Small HJ, Pagenkopp KM, Reece KS (2010) Detection and quantification of the free-living stage of the parasitic dinoflagellate Hematodinium sp. in laboratory and environmental samples. Harmful Algae 9: 515-521

> Litaker RW, Vandersea MW, Kibler SR, Reece KS and others (2003) Identification of Pfiesteria piscicida (Dinophyceae) and Pfiesteria-like organisms using internal transcribed spacer-specific PCR assays. J Phycol 39:754-761

Litaker RW, Vandersea MW, Kibler SR, Reece KS and others (2007) Recognizing dinoflagellate species using ITS rDNA sequences. J Phycol 43:344-355

Maddison DR, Maddision WP (2005) MacClade 4.07: Analysis of phylogeny and character evolution. Version 4.07. Available at http://macclade.org/index.html

McMillen-Jackson AL, Bert TM (2004) Mitochondrial DNA variation and population genetic structure of the blue crab Callinectes sapidus in the eastern United States. Mar Biol 145:769-777

Medlin L, Elwood HJ, Stickel S, Sogin ML (1988) The characterization of enzymatically amplified eukaryotic 16Slike rRNA-coding regions. Gene 71:491-499

Messick GA (1994) Hematodinium perezi infections in adult and juvenile blue crabs Callinectes sapidus from coastal bays of Maryland and Virginia, USA. Dis Aquat Org 19: 77-82

Messick GA, Shields JD (2000) Epizootiology of the parasitic dinoflagellate Hematodinium sp. in the American blue crab Callinectes sapidus. Dis Aquat Org 43: $139-152$

Milliken MR, Williams AB (1984) Synopsis of biological data on the blue crab, Callinectes sapidus Rathbun. FAO Fisheries Synopsis No. 138, NOAA Tech Rep. National Marine Fisheries Service, Silver Spring, MD

Moss JA, Burreson EM, Cordes JF, Dungan CF and others (2007) Pathogens in Crassostrea ariakensis and other Asian oyster species: implications for non-native oyster introduction to Chesapeake Bay. Dis Aquat Org 77 : 207-223

> Moss JA, Xiao J, Dungan CF, Reece KS (2008) Description of Perkinsus beihaiensis n. sp., a new Perkinsus sp. parasite in oysters of southern China. J Eukaryot Microbiol 55: $117-130$ 
Musters W, Boon K, van der Sande CAFM, van Heerikhuizen H, Planta RJ (1990) Functional analysis of transcribed spacers of yeast ribosomal DNA. EMBO J 9: 3989-3996

Newman MW, Johnson CA (1975) A disease of blue crabs (Callinectes sapidus) caused by a parasitic dinoflagellate, Hematodinium sp. J Parasitol 61:554-557

Pagenkopp Lohan KM, Reece KS, Miller TL, Wheeler KN, Small HJ, Shields JD (2012a) The role of alternate hosts in the ecology and life history of Hematodinium sp., a parasitic dinoflagellate of the blue crab (Callinectes sapidus). J Parasitol 98:73-84

Pagenkopp Lohan KM, McDowell JR, Shields JD, Xiao J, Miller TL, Reece KS (2012b) Isolation and characterization of microsatellite loci for the parasitic dinoflagellate, Hematodinium perezi, a parasite of Callinectes sapidus. Mol Ecol Resour 12:570-572

Pelc RA, Warner RR, Gaines SD (2009) Geographical patterns of genetic structure in marine species with contrasting life histories. J Biogeogr 36:1881-1890

Reece KS, Bushek D, Hudson KL, Graves JE (2001) Geographic distribution of Perkinsus marinus genetic strains along the Atlantic and Gulf coasts of the USA. Mar Biol 139:1047-1055

Schlötterer C, Hauser MT, von Haeseler A, Tautz D (1994) Comparative evolutionary analysis of rDNA ITS regions in Drosophila. Mol Biol Evol 11:513-522

Small HJ (2012) Advances in our understanding of the global diversity and distribution of Hematodinium spp. - significant pathogens of commercially exploited crustaceans. J Invertebr Pathol 110:234-246

Small HJ, Pagenkopp KM (2011) Reservoirs and alternate hosts for pathogens of commercially important crustaceans: a review. J Invertebr Pathol 106:153-164

Editorial responsibility: Grant Stentiford, Weymouth, UK
Small HJ, Shields JD, Moss JA, Reece KS (2007a) Conservation in the first internal transcribed spacer region (ITS1) in Hematodinium species infecting crustacean hosts found in the UK and Newfoundland. Dis Aquat Org 75: 251-258

Small HJ, Shields JD, Hudson KL, Reece KS (2007b) Molecular detection of Hematodinium sp. infecting the blue crab, Callinectes sapidus. J Shellfish Res 26:131-139

Small HJ, Shields JD, Haas LW, Vogelbein WK, Moss JA, Reece KS (2009) Genetic variation among strains of Pseudopfiesteria shumwayae and Pfiesteria piscicida (Dinophyceae). J Phycol 45:1315-1322

Small HJ, Shields JD, Reece KS, Bateman K, Stentiford G (2012) Morphological and molecular characterization of Hematodinium perezi (Dinophyceae: Syndiniales), a dinoflagellate parasite of the harbour crab, Liocarcinus depurator. J Eukaryot Microbiol 59:54-66

Stentiford GD, Shields JD (2005) A review of the parasitic dinoflagellates Hematodinium species and Hematodinium-like infections in marine crustaceans. Dis Aquat Org 66:47-70

- Tamura K, Peterson D, Peterson N, Stecher G, Nei M, Kumar S (2011) MEGA5: Molecular evolutionary genetics analysis using maximum likelihood, evolutionary distance, and maximum parsimony methods. Mol Biol Evol 28: 2731-2739

> Templeton AR, Crandall KA, Sing CF (1992) A cladistic analysis of phenotypic associations with haplotypes inferred from restriction endonuclease mapping and DNA sequence data. III. Cladogram estimation. Genetics 132:619-633

Zheng X, Cai D, Yao L, Teng Y (2008) Nonconcerted ITS evolution, early origin and phylogenetic utility of ITS pseudogenes in Pyrus. Mol Phylogenet Evol 48:892-903

Submitted: May 24, 2012; Accepted: November 12, 2012 Proofs received from author(s): March 6, 2013 